\title{
リンの有害な作用とその除去上の問題点
}

\author{
秋 澤 忠男・越 川 昭 三 \\ 昭和大学藤が丘病院 内科 227 横浜市緑区藤が丘 $1-30$
}

\section{Uremic Toxities and Dialytic removal of Phosphate}

\section{Tadao Akizawa and Shozo Koshikawa}

Department of nephrology, Internal Medicine, Fujigaoka Hospital, Showa University, 1-30 Fujigaoka, Midori-ku, Yokohama 227

Phosphate $(\mathrm{P})$ retention, resulted from renal insufficiency directly or indirectly provides pathogenetic roles to the human body. $\mathrm{P}$ related signs and symptoms include osteodystrophy, metastatic calcification, central or peripheral neuropathy, anemia, cardiomyopathy, lipid and carbohydrate mal-metabolisms, immunodysfunctions and so on. From these pathological effects of P, P is regarded as one of the major uremic toxins. In spite of the small molecular weight of $\mathrm{P}, \mathrm{P}$ always shows lower dialysis efficiency than urea. This result can be partially explained by the interaction between negatively charged $\mathrm{P}$ and dialysis membrane. Although computer simulation model represented the increase in dialysis efficiency of $\mathrm{P}$ across the positively charged membranes, these membranes have not been clinically available. Dialysis membrane with larger membrane pore size and increased porosity significantly stimulated the $\mathrm{P}$ removal, however dialysis efficiency of $\mathrm{P}$ remained still lower than urea. From these results, it is strongly expected that membrane technology will succeed in the development of new dialysis membrane with more effective $\mathrm{P}$ removal.

Key words : Phosphate, Uremic toxin, Charged membrane, Dialysis efficiency, High-performance membrane

\section{はじめに}

生体にとって, リン $(\mathrm{P})$ は細胞膜や骨格の主要な構 成成分であるばかりでなく，エネルギー伝達物質として 必須のイオンである.P は腸管から吸収されるが, P の 唯一の排泄器官は腎臓で, 末期腎不全に陥ると $\mathrm{P}$ 貯留に 伴う諸症状が出現, P は尿毒症性貯留物質 (uremic toxins)の一つに数えられている.

本稿では, こうしたPの生体内分布と出納, 蓄積に伴 う病態と除去に伴う問題点を, 臨床的観点から概説する.

\section{Pの生体内分布}

健康な成人の生体には約 $800 \mathrm{~g}$ の $\mathrm{P}$ が含まれ, 骨格系 に $85 \%$ が, 残りの大部分は筋肉に存在する.P は主とし て細胞内にリン脂質・核酸などの有機リンとして存在 し，一部は無機リンとしてATP や諸酵素合成に用いら れる. 血清中で通常測定されるのは無機リンで, $\mathrm{H}_{2} \mathrm{PO}_{4}^{-}$ と $\mathrm{HPO}_{4}{ }^{2-}$ の 2 つ形で存在, 血清 $\mathrm{pH}$ と HendersonHasselbalch の式 
$\mathrm{a}:$ trade off 仮説

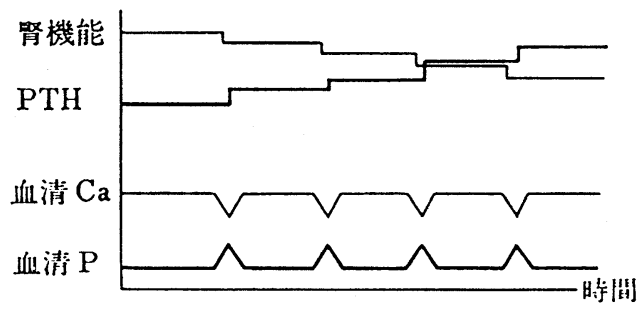

b : ビタミン D主犯説

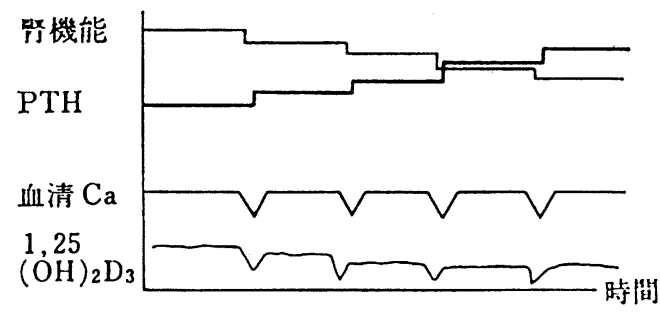

図 1. 二次性副甲状腺機能六進症の発症機序 $\mathrm{P}$ の蓄積が直接 (上段) あるいは活性型ビタミンD の低下（下段）を介して血清 Ca を抑制, PTH が 上昇する。

$$
\begin{aligned}
& \mathrm{pH}=\mathrm{pk}+\log \mathrm{HPO}_{4}{ }^{2-} / \mathrm{H}_{2} \mathrm{PO}_{4}^{-}, \mathrm{pk}=6.8, \\
& \mathrm{pH}: 7.35 \sim 7.45 \text { から, } \mathrm{H}_{2} \mathrm{PO}_{4}^{-}: \mathrm{HPO}_{4}{ }^{2-}=1: 4
\end{aligned}
$$

の比率となる.

\section{2. $\mathrm{P}$ の出納と腎機能の影響}

食物の $\mathrm{P} の$ 含有量はタンパク量に強く依存し, 通常の タンパク摂食下では一日約 $1 \mathrm{~g}$ のPが摂取されるが，リ ン酸塩を添加した加工食品（ハム，スナック菓子など） では， P 摂取量は飛躍的に増加する．食物中の $\mathrm{P}$ は主と して小腸で吸収され，腸管からの分泌之相殺して吸収量 は摂取量の $70 \%$ 程度である。腎機能が正常であれば吸 収量に見合う $\mathrm{P}$ は尿中に排泄され, $\mathrm{P}$ 出納の平衡は保た れる．腎機能が低下すると P 排泄は減少，P の恒常性 を保つために腎臓の種々の代償機構が作用してP排泄は 一時的に増加する. 代表的な代償機構が副甲状腺ホルモ ン (parathyroid hormone : PTH) の増加で, PTH は 腎臓の尿細管での $\mathrm{P}$ 再吸収を抑制, 結果的に $\mathrm{P}$ 排泄は増 加する。

こうした代償機構も腎病変が進行，腎機能がさらに悪 化すると適応しきれず，末期腎不全に至ると $\mathrm{P}$ 蓄積（高 P血症）と PTH の著増が存在することになる（図 1). このような腎不全に起因する $\mathrm{PTH}$ の上昇を 2 次性副甲
表 1 ． 有害物質としての $\mathrm{P}$ の作用

1. 直接的作用

異所性石灰化

PTH 分泌促進 腎性骨異栄養症 $1.25(\mathrm{OH}) 2-\mathrm{VitD} 3$ 産生抑制

2. 間接的作用 (PTH を介する) 中枢，末梢神経障害 腱断裂 貧血性機能異常 心筋障害筋肉障害 高脂血症成長遅延 糖代謝異常少伝導障害 搔㾕症肺拡散障害 皮膚虚血性潰瘍動脈硬化 関節障害免疫不全

状腺機能六進症 (secondary hyperparathyroidism : $\left.2^{\circ} \mathrm{HPT}\right)$ と呼ぶ.

\section{Uremic toxin としてのP}

腎機能低下に伴い体内に貯留し，尿毒症症状の起因物 質となる uremic toxins には，水やKを始め，小分子 から大分子量物質に至るまで 100 を超える物質が想定さ れている，蓄積した $\mathrm{P} に$ 疑われる有毒な作用としては （表 1), 直接的作用として PTH の産生・分泌促進の他, 異所性石灰化やビタミンDの活性化抑制がある．異所性 石灰化は骨以外の組織に Ca, P の異常沈着をきたす病 態で，特に血管壁の石灰化は動脈硬化の重要な促進因子 となる．ビタミン Dは体内の $\mathrm{Ca}$ ・骨代謝を規定する重 要なホルモンで, 腎臟で活性化されて生理的作用を発揮 する，活性化の抑制は骨障害をもたらすだけでなく，ビ タミンDが PTH の分泌を抑制することから $2^{\circ} \mathrm{HPT}$ の 病因としても作用する．間接的作用は PTH を介する病 態が主因で, PTH は表 1 に示すように広範な生体に有 害な作用を持つ。

末期腎不全で透析療法に移行しても，P の恒常性が維 持されない限り上述した病態は持続することから, 数十 年の単位で透析療法によって管理せざるを得ない透析患 者の長期的な合併症に，P 貯留が重要な役割を演じるこ とが理解できる. 


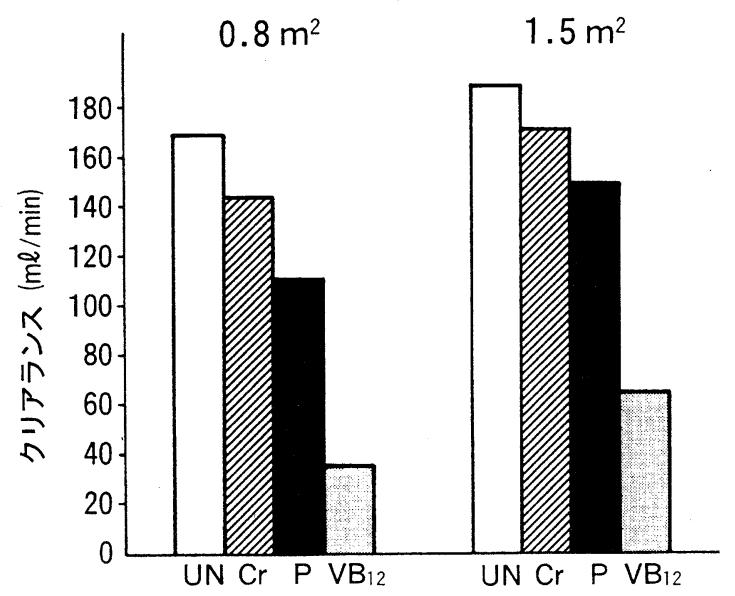

図 2. 通常の透析器の溶質クリアランス ${ }^{1)}$

\section{4. 透析患者の $P$ 出納}

生体に有毒な作用を持つ $\mathrm{P}$ の蓄積を防止するには，1） $\mathrm{P}$ 制限食, 2) $\mathrm{P}$ 吸着剤を投与して翼便中への $\mathrm{P}$ 排泄を増 加させる，3）尿中への $\mathrm{P}$ 排泄増加，4）透析による $\mathrm{P}$ 除 去の増加の 4 つの対策が考えられる. 長期透析患者の場 合, 腎機能は廃絶して尿量はほぼゼロであり, 利尿剤を 投与しても尿中への $\mathrm{P}$ 排泄を期待することはできない。 $\mathrm{P}$ 制限は食事のタンパク制限につながり, 筋肉萎縮や筋 力低下を高率に合併する透析患者では protein mal-nutrition の増悪が䯚念される。 また, 食事中の $\mathrm{P}$ と $\mathrm{Ca}$ は 相関することから, P 制限が Ca の摂取不足をもたらす 可能性もある.

$\mathrm{P}$ 吸着剤としてはアルミニウム $(\mathrm{Al})$ 製剂が長期間使 用されてきたが, $\mathrm{Al}$ が腸管から吸収され, 脳症や骨軟 化症, 貧血などの原因となる事実が明らかとなり, 炭酸 $\mathrm{Ca}$ や酢酸 $\mathrm{Ca}$ などの $\mathrm{Ca}$ 製剤に変更されるようになっ た. しかし $\mathrm{Ca}$ 製剤の $\mathrm{P}$ 吸着作用は $\mathrm{Al}$ より弱く, 吸着 作用の $\mathrm{pH}$ 依存性も高いことから $\mathrm{P}$ のコンロールには 大量を要し, 大量投与は服薬の難しさとともに Ca の過 㮃負荷から高 $\mathrm{Ca}$ 血症をもたらし, $2^{\circ} \mathrm{HPT}$ や骨障害を 防止する活性型ビタミンD製剤の減量を余儀なくされる という新たな問題点が出現する.したがって, 現状では 透析による P 除去量の増加が対処し得る唯一の方法と して注目されるに至っている.

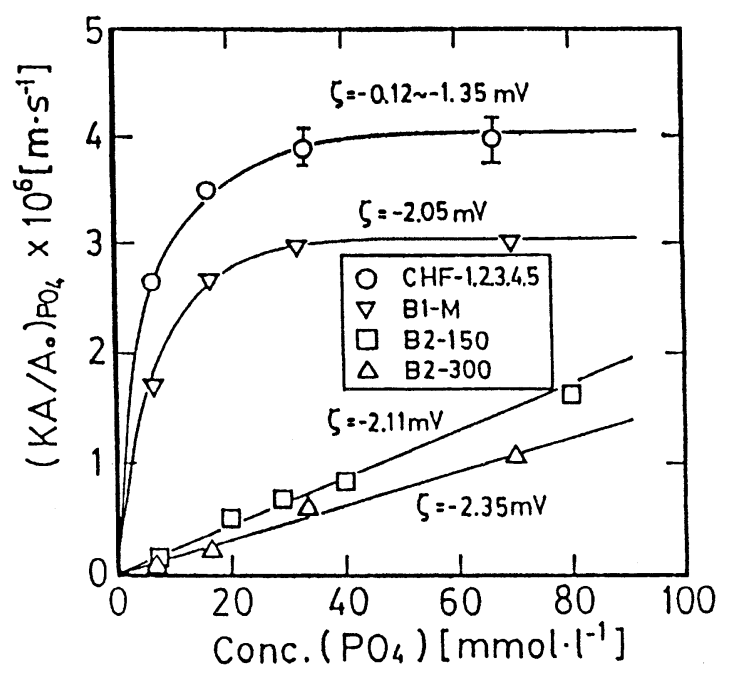

図 3. 無機リンの総括物質移動係数と無機リン濃 度の関係 $^{3)}$

\section{5. 血液透析における $\mathrm{P}$ 除去の特徵}

\section{1. 膜荷電の影響}

血液透析の溶質除去能の指標には, 臨床的にはクリア ランスが多用される。透析膜の溶質クリアランスの第一 の規定因子は溶質の分子量である. 無機 $\mathrm{P}$ は荷電量にか かわらず血清中では尿素やクレアチニンと同様の小分子 物質で, これらと同等のクリアランスが期待される.し

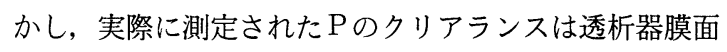
積にかかわらず低值で') (図 2), 分子量以外の要因が関 与すると考えられる.

\section{1. 1. 理論的解析}

こうした因子として考えられているのが膜荷電であ る. 透析膜は一般に陰性に荷電しており, P イオンの陰 性荷電と電気的な反発が生じることにより, P のクリア ランスが尿素などの非荷電性物質に比して低下する機序 が報告された。この現象を詳細に検討した早稲田大学の 酒井らは2 ${ }^{20}$, 各透析膜の膜電位や膜表面電位（ゼ一 夕電位）と無機リンの溶質透過性を検討し，これらの電 位がPの透過性に影響を及ぼしていることを明らかにし た. 各種のゼー夕電位を持つよう改質された再生セル ロース膜および polymethylmethacrylate (PMMA) 膜中空糸のゼー夕電位と Pの総括物質移動係数の関係を みると, 移動係数は P 濃度に依存し, PMMA 膜では再 生セルロース膜より移動係数は低く（図 3), さらに再 生セルロース膜ではゼー夕電位と移動係数の間に関連は 


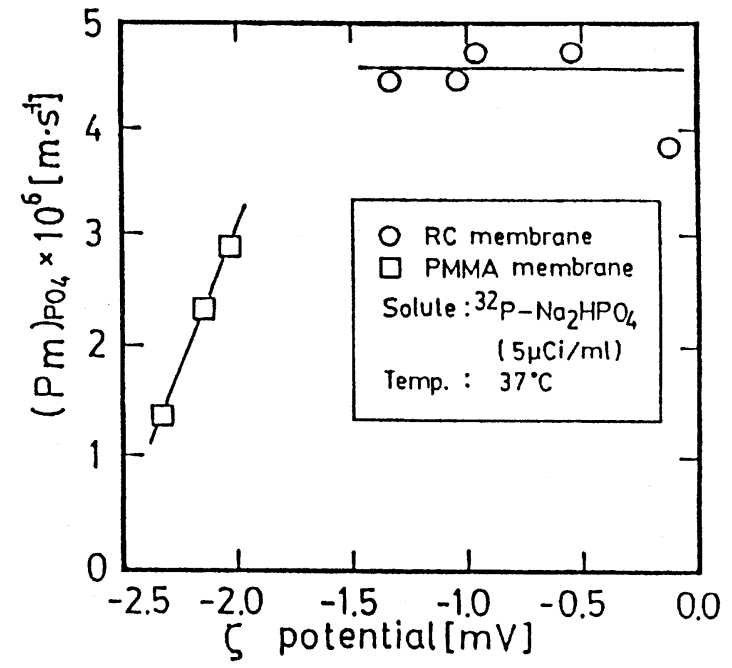

図 4. 無機リンの溶質透過係数と $\zeta$ 電位の関係 ${ }^{3)}$
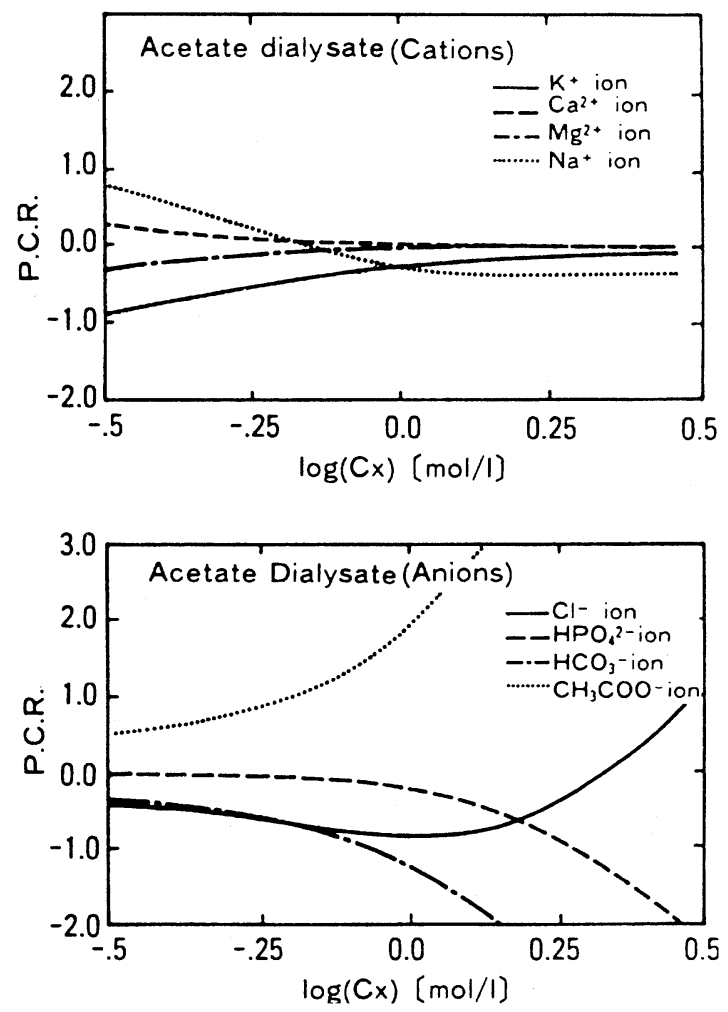

図 5. 酢酸透析液における膜荷電とイオン透過係 数比 $(\mathrm{PCR})^{8)}$

みられないのに対し, PMMA 膜ではゼー夕電位が負に傾 くに従いPの透過性が減少することが示された (図 4) ${ }^{3)}$. これらの一連の実験で, ゼー夕電位と膜内電位は膜の
膜 (MEMBRANE), Vol. 17 No. 1 (1992)

15

表 2. 透析膜の膜荷電とイオン透過性の解析に用い られた患者血清と透析液電解質組成

\begin{tabular}{|c|c|c|c|}
\hline 電解質 & 血 清 & 䣷酸透析液 & 重炭酸透析液 \\
\hline $\mathrm{Na}$ & 140 & 130 & 135 \\
\hline $\mathrm{K}$ & 5 & 2 & 2 \\
\hline $\mathrm{Ca}$ & 2.5 & 3 & 3 \\
\hline $\mathrm{Mg}$ & 2 & 1 & 1 \\
\hline $\mathrm{Cl}$ & 105 & 101 & 105 \\
\hline $\mathrm{HCO}_{3}$ & 20 & 0 & 30 \\
\hline $\mathrm{HPO}_{4}$ & 10 & 0 & 0 \\
\hline $\mathrm{CH}_{3} \mathrm{COO}$ & 0 & 35 & 8 \\
\hline
\end{tabular}

種類により必ずしも一致しないこと，血液側あるいは透 析液側溶液の濃度が高まりイオン強度が増加すると膜内 に陽イオンが進入して膜は電気的に見かけ上中性とな り, P の総括移動係数が大きく上昇すること，この現象 は陽イオンの移動度に依存すること, 血清系では水系に 比して移動係数は大きく, 血清タンパクの膜内荷電に与 える影響が疑われること, さらに膜の荷電状態以外の膜 構造なども透過性を規定する因子となることなどの成果 が明らかとなっだ 6).

一方, 東京工大の谷岡らは, multi-ion system にお けるイオン透過現象の理論式から, 膜荷電を変化させた 際の各種イオンの出納を実際の治療に即したモデルで解 析する方法を考案した ${ }^{7 ~ 9)}$. 本モデルにしたがえば, 表 2 の条件で治療される患者の透析膜荷電と電解質出納 は, 膜電位ゼ口の電気的中性膜における $\mathrm{KCl}$ 溶液のイ オン透過係数を 1 とした際のイオン透過係数比 (PCR) を用いると, 図 5 , 図 6 のように表わすことができる. まず酢酸透析液を用いた場合, 膜荷電か陰性に傾くに従 い $\mathrm{K}, \mathrm{Mg}$ の透析液側への移動は増加し, Ca の体内へ の流入も增加する.

一方, 陰イオンでは, 膜荷電が陽性になるにしたがい, リンや重炭酸の除去量は増し, 酢酸の体内への移動量は 増加する (図 5)。つぎに重炭酸透析液を用いた場合に は，陽イオンは酶酸透析之同様の動きを示すのに対し， リンは陽性膜荷電になるほど除去されやすく, 酷酸と重 炭酸は体内に流入しやすくなる $(\text { 図 6 })^{8,9)}$. 酢酸, 重 炭酸のいずれの透析液を用いても, リンに関する限り, 膜荷電が陽性になる程効率的な除去が期待できることが 概念的には理解することができる. 

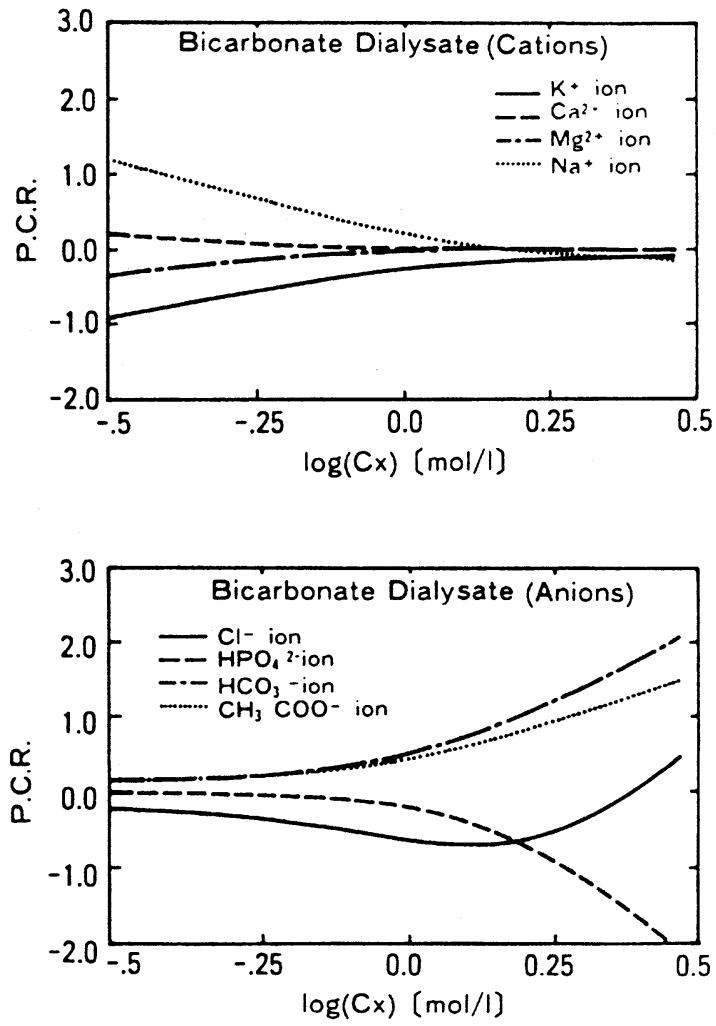

図 6. 重炭酸透析液における膜荷電とイオン透過 係数比 $(\mathrm{PCR})^{8)}$

\subsection{2. 臨床的検討}

こうした理論的裏付から, 負荷電の強い膜電位やゼ一 夕電位を持つ膜素材の透析器では, 尿素などに比し, P の除去性能は相対的に低下する可能性が考えられる. in vitro の尿素クリアランスに差のない 3 種の中空糸膜透 析器を, 10 名の患者に同一透析条件下でクロスオー バーで使用して小分子物質クリアランスを比較したわれ われの成績では, 陰性膜荷電の強い PMMA 膜で, 再 生セルロース膜の遊離 $\mathrm{OH}$ 基を 3 級アミンで置換して 相対的に陽荷電化したへモファン膜や, 陰性膜荷電が $\mathrm{P}$ MMA より弱い cellulose acetate 膜に比し, P クリア ランスは有意の低下を示した ${ }^{10)}$ (図 7). 他の小分子物 質のクリアランスに差はみられなかったことから，Pク リアランスの差異は膜電位の相違に起因すると推定され る.こうした差異は透析前後のP の除去率にも認められ, 膜荷電の差異が実際の治療時にも影響を及ぼしていると 考えられる.

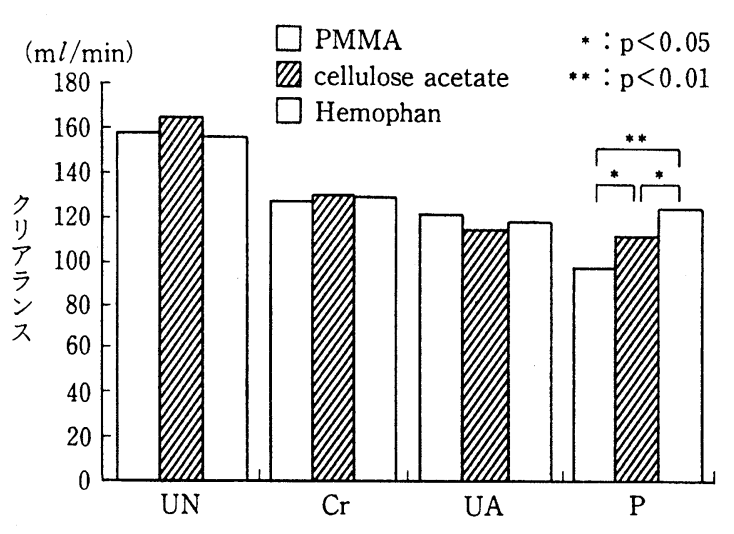

図 7. 透析器膜素材と小分子物質のクリアランス ${ }^{10)}$

\section{2. $\mathrm{P}$ の体内動態}

透析により溶質が血中から除去されると, 細胞間質や 細胞内から蓄積した溶質が血中に移動するが，透析療法 を継続している限り血中濃度が増加することはない. 図 8 に透析中の尿素窒素と P の経時的変化を示す ${ }^{11)}$. 細 胞内外の移動速度のきわめて速い尿素窒素でさえ, 透析 中は血中濃度が持続的に低下するのに対し, P は透析後 半に血中濃度がプラトーとなるか, 上昇するリバウンド 現象を示す.この現象はきわめて不可解で, P が透析に より血中から持続的に除去されていること, 透析による アシドーシスの改善から, アシドーシスに伴い細胞内か ら細胞外へ遊離していたPイオンは細胞内に追い込まれ ることなどから，リバウンド現象の機序を説明すること は困難である.この問題を長年研究してきた杉崎による $亡^{12 \sim^{15)}}$, リバウンド現象に対する溶血, タンパクと 結合したPの溶出, 透析中の食事摂取, 血液膜間相互作 用による血球からの移動の関与は全て否定され, 筋肉や 骨を含めた細胞系が構成する P-reservoir からの急激 な溶出が想定されるという.

透析療法の効率の観点からリバウンド現象をみると, 透析によりできるだけ多くを除去する必要がありなが ら, その陰性荷電から通常の透析膜では他の小分子物質 ほよ゙効率良く除去できないPが, リバウンドで血中に増 加するのであれば，この現象を利用してより大量のPを 除去できる可能性が期待できる.

\section{6. リン除去能向上への試み}

透析膜の負荷電がP の膜透過性を阻害する重要な要因 であり, 理論的には陽性荷電膜で P 除去能の向上が示唆 
透析器 $\mathrm{A}$

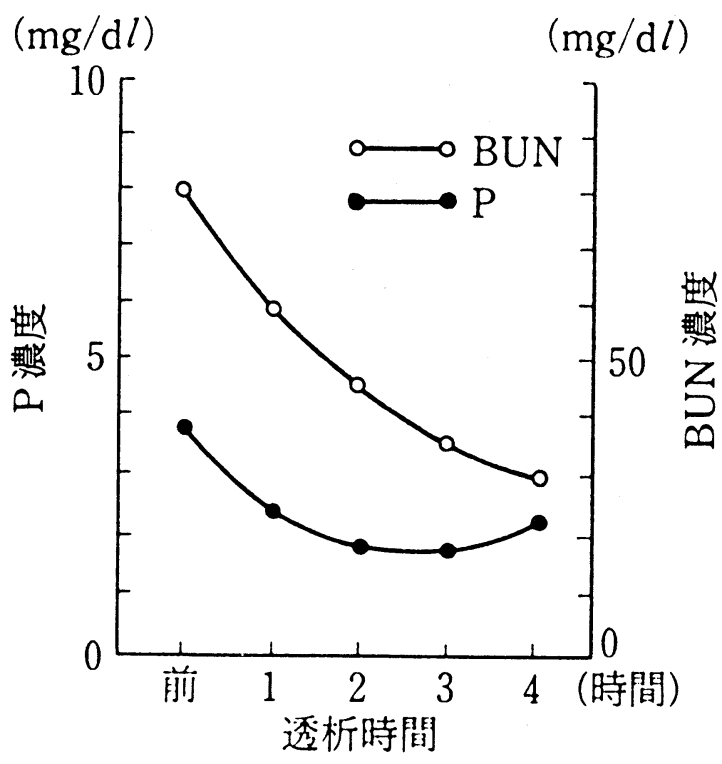

透析器 $\mathrm{B}$

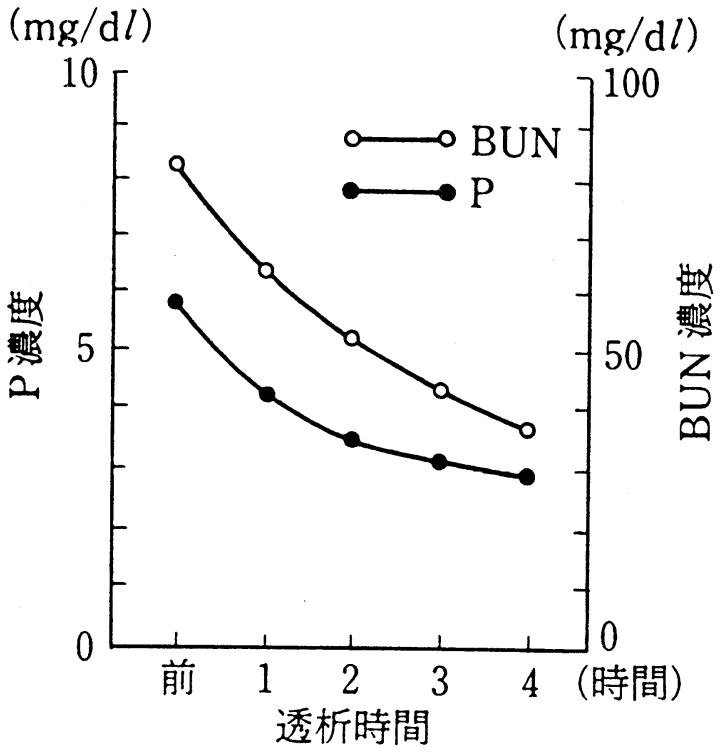

図 8. 血液透析中の $\mathrm{BUN}$ と血清 $\mathrm{P}$ 濃度の変化 ${ }^{11}$

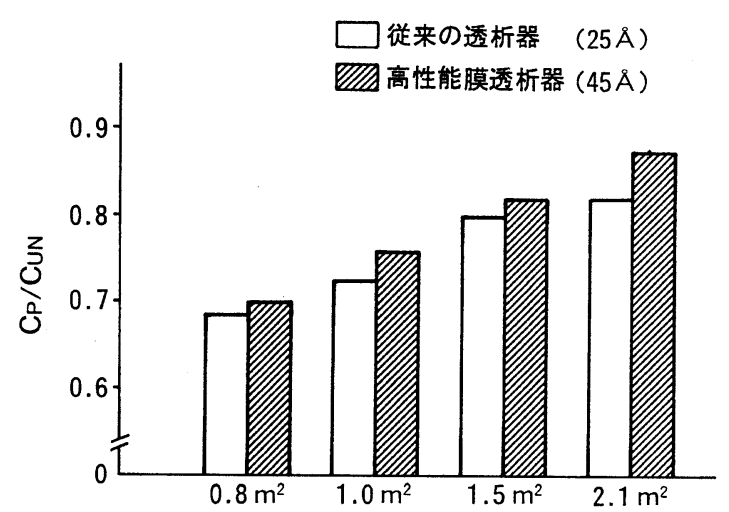

図 9. 尿素クリアランスに対するPクリアランス 比 ${ }^{10}$

されることから, 陽性荷電膜の開発が期待されたが，現 在の所実用化された透析膜は皆無である. 他の溶質の透 過性, 血小板活性化などの生体反応などの解決すべき問 題点は多いが，膜開発の 1 つの方向として取り組まれる べき課題といえる.

膜荷電の影響を最大限に抑える方法として, 現在行わ れているのが膜孔の拡大である. 膜孔の拡大から $\mathrm{P}$ 透過 に際しての電気的反発は抑制され，尿素とPのクリアラ ンスの比で測定したPの相対的な膜透過性能は，いずれ の膜面積でも膜孔の拡大で有意に増加した（図 9) ${ }^{10)}$.

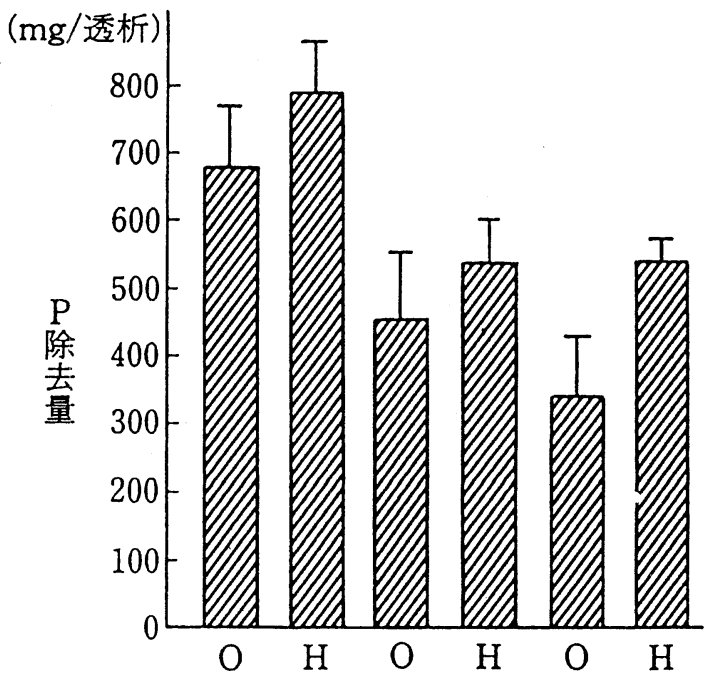

図 10. 各種膜素材からなる通常の透析器 $(O)$ と high performance 膜透析器 $(\mathrm{H})$ 使用時 の透析液中へのP P 除去量 ${ }^{11}$, 16)

こうした効果を臨床的に確認するため, 再生セルロース, PMMA, ethylenevinylalcohol (EVA) の 3 種の膜素 材からなる従来の透析器と, 膜面積が等しく, 膜孔を拡 大した high performance 膜透析器を同一患者にクロ スオーバーで使用して透析液中の $\mathrm{P}$ 排泄量を比較する と, いずれの膜素材でも high performance 膜透析器 
で，P 排泄量は有意の増加を示した（図 10) ${ }^{11.16)}$ 。こ のように, 膜孔の拡大は $\mathrm{P}$ 除去能を向上させる一つの対 策として成功はしたが, 図 9 から明らかなように, リン と尿素のクリアランス比は high performance 膜でも 1.0 に達しておらず, P 除去性能にはもう一段の改善の 余地が残されている.

$\mathrm{P}$ 除去を向上させる対策としては，これらの他に透析 液をカチオン化し, 陽性荷電膜を使用したの之同様の効

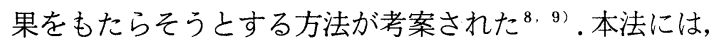
理論上は $\mathrm{P}$ 除去増加効果が期待できるが, 透析液が非生 理的組成となるのを避けられず, 臨床的実用化は困難で ある. 一方, アシドーシスでは細胞内の Pが血清中に溶 出, アルカローシスでは逆の現象が生じることから, 透 析中の酸塩基平衡の改善速度をできるだけ緩徐にし, P の効率的除去を図る方法も試みられたが 17), 明らかな 効果を発揮するには至らなかった.

\section{おわりに}

腎不全患者にとって $\mathrm{P}$ は蓄積を避けなければならない toxin であり, 蓄積防止には透析療法による効率の高い 除去が不可欠である. 現行の透析技術には, P 除去に関 してなお改善の期待できる余地があり, 特に透析膜の改 良と発展はその根幹を成すと言える. 臨床医として, 関 係の方々のこうした問題に対するご理解とご支援を心か らお願いして, 本総説のむすびとしたい.

\section{文献}

1) 秋澤忠男他. 血液浄化法とリン除去. $\mathrm{HD}, \mathrm{HF}$, HDF一臨床面から. 臨床透析 7 : 1467, 1991

2) 内藤 明, 酒井清孝他. 体内イオンの膜透過に及ぼ す膜荷電の影響. 人工臟器 $16: 703,1987$

3) 内藤 明, 酒井清孝他. 血液透析膜のイオン透過性
と膜表面電位. 人工臓器 $17: 65,1988$

4) Okada M, Sakai K, et al : Effects of zetapotential on the permeability of dialysis membrane to inorganic phosphate. Trans Am Soc Artif Intern Organs $35: 320,1989$

5) 岡田 勝, 酒井清孝他. 透析膜における無機リンイ オンの膜透過性. 人工臓器 $19: 805,1990$

6）荻原一仁, 酒井清孝他. 無機リンの透析膜透過性に 与えるイオン強度の影響. 人工臓器 $20: 65,1991$

7) Higa M, Tanioka A, et al. Stimulation of the transport of ions against their concentration gradient across charged membranes. J Membr Sci $37: 251,1988$

8) Higa M, Tanioka A, et al. A study of ion permeability across a charged membrane in multicomponent ion systems as a function of membrane change density. J Membr Sci 49 : 145, 1990

9）永井哲士, 谷岡明彦他. Charged membraneにお ける荷電物質透過性の基礎的検討. 人工臟器 19 : 800,1990

10）秋澤忠男他. リン除去を促進する血液浄化法. 一膜 孔と荷電の影響. 透析会誌 $22: 1299,1989$

11）雨宮 均他. 各種透析器のリン除去能について. 腎 と透析 $27: 949,1989$

12) Sugisaki $H$, et al. Phosphate in dialysis patients. Trans Am Soc Artif Intern Organs 29 : 38,1983

13）杉崎弘章, 他. 透析患者におけるリンの出納と $\mathrm{P}$ 負 荷透析. 腎と透析 $19: 161,1985$

14）斧原三恵子, 杉崎弘章他. 血液透析によるリン除去 についての検討. 人工臟器 $14: 1842,1985$

15）杉崎弘章, 血液浄化法とリン除去, $\mathrm{HD}, \mathrm{HF}, \mathrm{HDF}$ 一膜の面から。臨床透析 $7: 1459,1991$

16) 雨宮 均, 他. High performance membrane 透 析器のリン除去能について. 腎と透析 25 (別冊) : 151,1988

17）織田みよ゙り他. 血液透析による効果的なリン除去法 の検討. 人工臓器 $19: 687,1990$

（受付 1991 年 12 月 2 日） 